\title{
Genomic resources of two landsnail, Aegista diversifamilia and Dolicheulota formosensis, generated by Illumina paired-end sequencing [version 1; peer review: 1 approved]
}

\author{
Chih-Wei Huang ${ }^{1}$, Wen-Lung Wu ${ }^{2}$ \\ ${ }^{1}$ Department of Life Science, National Taiwan Normal University, Section 4, Taipei, 11677, Taiwan \\ ${ }^{2}$ Biodiversity Research Center, Academia Sinica, Nankang District, Taipei, 11529, Taiwan
}

V1 First published: 06 May 2015, 4:106

https://doi.org/10.12688/f1000research.6447.1

Latest published: 06 May 2015, 4:106

https://doi.org/10.12688/f1000research.6447.1

\section{Abstract}

Despite the land snail harboring high biodiversity and dominance on land, just a few genetic markers are available for phylogeographic and phylogenetic research. We sequenced the partial genome of two land snail species that belong to the speciose family Bradybaenidae in East Asia: Aegista diversifamilia and Dolicheulota formosensis. The raw sequences were generated by Illumina paired-end sequencing and can be accessed in the Sequence Read Archive under the accession numbers SRR1918809 (A. diversifamilia) and SRR1920140 (D. formosensis).

\section{Keywords}

Helicoidea, Next-generation sequencing, Pulmonata, Stylommatophora

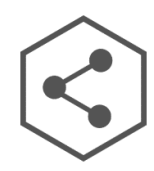

This article is included in the Data: Use and

Reuse collection.

\section{Peer review discontinued}

Peer review at F1000Research is authordriven. Currently no reviewers are being invited. What does this mean?

Approval Status
Valdivia, Chile
Any reports and responses or comments on the
article can be found at the end of the article.


Corresponding author: Chih-Wei Huang (limnoperna@gmail.com)

Competing interests: No competing interests were disclosed.

Grant information: This research was partially supported by the grant to Wen-Lung Wu from the Center for Information Technology Innovation and Biodiversity Research Center, Academia Sinica.

Copyright: $\odot 2015$ Huang CW and Wu WL. This is an open access article distributed under the terms of the Creative Commons Attribution License, which permits unrestricted use, distribution, and reproduction in any medium, provided the original work is properly cited. Data associated with the article are available under the terms of the Creative Commons Zero "No rights reserved" data waiver (CC0 1.0 Public domain dedication).

How to cite this article: Huang CW and Wu WL. Genomic resources of two landsnail, Aegista diversifamilia and Dolicheulota formosensis, generated by Illumina paired-end sequencing [version 1; peer review: 1 approved] F1000Research 2015, 4:106 https://doi.org/10.12688/f1000research.6447.1

First published: 06 May 2015, 4:106 https://doi.org/10.12688/f1000research.6447.1 


\section{Introduction}

Stylommatophora is the dominant gastropod clade on land. The family Bradybaenidae is mainly distributed in Asia and diversified in East Asia. However, only a handful of genetic markers are available for phylogenetic research. We selected two land snail species as representatives of Bradybaenidae: Aegista diversifamilia Huang et al., 2014 and Dolicheulota formosensis (H. Adams, 1866). We subjected these species to Illumina paired-end sequencing in the hope that this will expand and provide valuable genetic resources for phylogeographic and phylogenetic research of gastropods.

\section{Materials and methods}

Genomic sequences were generated from one fresh specimen preserved at $-20^{\circ} \mathrm{C}$ (A. diversifamilia) and one two-year-old ethanolpreserved specimen (D. formosensis), respectively. The living individual of $A$. diversifamilia was collected from leaf litter under lowland broadleaf forest in Xiulin Township, Hualien County, Taiwan in October 2013. D. formosensis was collected from the tree trunk of a lowland broadleaf forest in Mudan Township, Pingtung County, Taiwan in June 2012. Snails were brought back to laboratory and rinsed with $\mathrm{ddH}_{2} \mathrm{O}$ to eliminate soil and other particles attached to the shell. The living individual of A. diversifamilia was preserved in a $-20^{\circ} \mathrm{C}$ refrigerator. The individual of $D$. formosensis was relaxed under water for 12 hours and fixed by blanching with boiling water for several seconds. The specimen of $D$. formosensis was transferred to $95 \%$ ethanol solution and the ethanol was changed every 24 hours for 48 hours. The specimen of $D$. formosensis was finally preserved in $95 \%$ ethanol.

For A. diversifamilia, the shell was removed after the snail was crushed. Soft tissue was rinsed with TEK buffer $(50 \mathrm{ml} 1 \mathrm{M}$ Tris- $\mathrm{HCl}$ $\mathrm{pH} 7.5,50 \mathrm{ml}$ 0.2M EDTA $\mathrm{pH} 7.5,15 \mathrm{~g} \mathrm{KCl}, \mathrm{pH} 7.5)$ and then used for genomic DNA extraction with AxyPrep ${ }^{\mathrm{TM}}$ Multisource Genomic DNA Miniprep Kit (Axygen Bioscience) following the manufacturer's protocol. For D. formosensis, partial foot tissue was rinsed with $\mathrm{ddH}_{2} \mathrm{O}$ several times to remove ethanol and then used for DNA extraction through a modified phenol-chloroform method (Jiang et al., 1997).

The quantity of extracted DNA solution was evaluated by Qubit ${ }^{\circledR}$ dsDNA HS Assay Kit (Life Technologies). The DNA concentration was $131 \mathrm{ng} / \mu \mathrm{L}$ (total mass $20.96 \mu \mathrm{g}$ ) and $52.9 \mathrm{ng} / \mu \mathrm{L}(5.92 \mu \mathrm{g})$ for $A$. diversifamilia and $D$. formosensis, respectively. The DNA solution was send to BGI (Shenzhen, China) for paired-end library construction with insert size of approximately 500 base pairs using a Paired-End DNA Sample Prep Kit (Illumina). Sequencing was performed using Illumina HiSeq2000 in BGI. Raw sequences data can be accessed in Sequence Read Archive under accession number SRR1918809 for A. diversifamilia and SRR1920140 for D. formosensis.

\section{Ethics policies}

Ethical approval for the animals used was not required. Both species used in this study were common and not under list of protected species in Taiwan.

\section{Author contributions}

All authors were involved in experimental design, manuscript preparation and approval of the final version to be published.

\section{Competing interests}

No competing interests were disclosed.

Grant information

This research was partially supported by the grant to Wen-Lung Wu from the Center for Information Technology Innovation and Biodiversity Research Center, Academia Sinica.

\section{Acknowledgments}

We would like to thank Genomics BioSci \& Tech (Taiwan) for the assistance of experimental design. Thanks for BGI (Shenzhen, China) for the service of sequencing.
Adams H: Descriptions of fifteen new species of land and freshwater shells from Formosa, collected by Robert Swinhoe, Esq., consul at Taiwan in that island. Proceedings of Zoological Society of London. 1866; 1866: 316-319. Reference Source

Huang CW, Lee YC, Lin SM, et al:: Taxonomic revision of Aegista subchinensis (Möllendorff, 1884) (Stylommatophora, Bradybaenidae) and a description of a new species of Aegista from eastern Taiwan based on multilocus phylogeny and comparative morphology. ZooKeys. 2014; 445: 31-55. PubMed Abstract | Publisher Full Text | Free Full Text

Jiang L, Wu WL, Lin YS: Efficient methods for isolating mitochondrial DNA from fresh or fixed molluscan specimens. Zoological Studies. 1997; 36(1): 74-78. Reference Source 


\title{
Peer review discontinued Peer review at F1000Research is author-driven. currently no reviewers are being invited. What does this mean?
}

\section{Version 1}

Reviewer Report 22 June 2015

https://doi.org/10.5256/f1000research.6918.r8910

(C) 2015 Opazo J. This is an open access peer review report distributed under the terms of the Creative Commons Attribution License, which permits unrestricted use, distribution, and reproduction in any medium, provided the original work is properly cited.

\begin{abstract}
Juan Opazo
Instituto de Ciencias Ambientales y Evolutivas, Facultad de Ciencias, Universidad Austral de Chile, Valdivia, Chile

This data note is reporting massive amount of genetic data for two landsnail species, with the aim that this resource will serve as a platform to develop phylogenetic and phylogeographic makers. The goal of this note is well justified given that for one of the genera, Dolicheulota, there are no NCBI entries, whereas for the other the diversity of them is low. Samples were sequenced using standard protocols in a facility that has experience in sequencing protocols. I am convinced that this data will be useful to the scientific community, especially to those interested in the evolutionary history of gastropods.
\end{abstract}

Competing Interests: No competing interests were disclosed.

I confirm that I have read this submission and believe that I have an appropriate level of expertise to confirm that it is of an acceptable scientific standard. 
The benefits of publishing with F1000Research:

- Your article is published within days, with no editorial bias

- You can publish traditional articles, null/negative results, case reports, data notes and more

- The peer review process is transparent and collaborative

- Your article is indexed in PubMed after passing peer review

- Dedicated customer support at every stage

For pre-submission enquiries, contact research@f1000.com 